\title{
Analisis Implementasi Pendidikan Keuangan pada Jenjang Pendidikan Anak Usia Dini (PAUD)
}

\author{
Novedi Risanti Langgi ${ }^{\bowtie}$, Susilaningsih ${ }^{1}$ \\ Pendidikan Ekonomi, Universitas Sebelas Maret, Indonesia(1) \\ DOI: 10.31004/obsesi.v6i3.1925
}

\begin{abstract}
Abstrak
Pendidikan keuangan penting untuk ditanamkan sejak usia dini. Penelitian ini akan menganalisis implementasi pendidikan keuangan pada jenjang Pendidikan Anak Usia Dini (PAUD) dan implikasinya terhadap pendidikan keuangan anak usia dini di Indonesia. Informan dalam penelitian ini adalah tiga orang guru PAUD yang berasal dari tiga lembaga PAUD yang berbeda di Kabupaten Ngawi. Metode penelitian yang digunakan adalah metode kualitatif dengan pendekatan studi kasus. Teknik pengumpulan data menggunakan wawancara mendalam dan analisis dokumen. Teknik analisis data menggunakan teknik analisis interaktif. Hasil penelitian menunjukkan bahwa tidak semua PAUD menerapkan pendidikan keuangan dalam pembelajarannya. Sementara PAUD yang telah menerapkan pendidikan keuangan pelaksanaannya masih belum optimal. Ketidak optimalan tersebut diantaranya adanya perbedaan materi pendidikan keuangan yang diajarkan guru dengan anjuran OJK, kurangnya sumber belajar yang memadai, dan tidak adanya sistem evaluasi formal. Implikasinya adalah pendidikan keuangan harus menjadi bagian dari kurikulum dan memiliki kerangka kerja yang jelas. Pelaksanaan pendidikan keuangan juga harus mendapatkan dukungan dari berbagai pihak.
\end{abstract}

Kata Kunci: pendidikan keuangan; anak usia dini; paud.

\begin{abstract}
Financial education is important to be instilled from an early age. This study will analyze the implementation of financial education at the Early Childhood Education level and its learning process on early childhood financial education in Indonesia. The informants in this study were three PAUD teachers from three different PAUD institutions in Ngawi Regency. The research method used is a qualitative method with a case study approach. Data collection techniques used in-depth interviews and document analysis. The data analysis technique used interactive analysis techniques. The results showed that not all PAUD implement financial education in their learning. Meanwhile, PAUD which has implemented financial education is still not optimal. These non-optimizations include differences in financial education materials taught by teachers with OJK recommendations, lack of adequate learning resources, and the absence of a formal evaluation system. The implication is that financial education should be part of the curriculum and have a clear framework. The implementation of financial education must also get support from various parties.
\end{abstract}

Keywords: financial education; early childhood; preschool.

Copyright (c) 2022 Novedi Risanti Langgi, Susilaningsih.

$\triangle$ Corresponding author :

Email Address : vedirisanti98@gmail.com (Ngawi, Jawa Timur, Indonesia)

Received 10 July 2021, Accepted 1 August 2021, Published 17 January 2022

Jurnal Obsesi : Jurnal Pendidikan Anak Usia Dini, 6(3), 2022 | 2429 


\section{PENDAHULUAN}

Keterampilan yang harus dikuasai pada abad 21 diantaranya adalah literasi dasar, kompetensi, dan karakter (World Economic Forum, 2015:2). Salah satu komponen dari literasi dasar yang sangat penting untuk dikuasai adalah literasi keuangan. Literasi keuangan merupakan pengetahuan dan pemahaman mengenai konsep dan risiko keuangan, serta keterampilan dan sikap untuk menerapkan pengetahuan tersebut dalam pengambilan keputusan keuangan yang efektif untuk meningkatkan kesejahteraan individu dan masyarakat (Organisation for Economic Co-operation Development, 2021:18). Perubahan dalam landskap keuangan dan maraknya penipuan mengharuskan seseorang memiliki literai keuangan yang baik (Goyal \& Kumar, 2021). Penelitian Sansone, Rossi, dan Fornero (2019) mengungkapkan bahwa individu dengan tingkat pemahaman keuangan yang baik akan dapat memanajemen keuangan pribadinya dengan baik pula. Temuan tersebut dibuktikan dengan fakta penelitian Kurowski (2021) yang menunjukkan bahwa seseorang yang memiliki kemampuan literasi keuangan cenderung dapat menghadapi pandemi Covid-19 dengan lebih baik dan terhindar dari jebakan utang.

Anak usia dini didefinisikan sebagai manusia dengan rentang usia antara 0 sampai 6 tahun yang sedang tumbuh dan berkembang dengan pesat, baik dari segi fisik maupun pikiran (Lestariningrum, 2017:2). Usia dini adalah periode di mana perilaku, kebiasaan, dan karakter seseorang dibentuk (Lian, Kristiawan, Primasari, Anggung, \& Prasetyo, 2020). Anak pada masa ini akan mengamati lingkungan maupun perbuatan orang-orang di sekelilingnya dan akan membentuk perilaku serta kebiasaan yang akan mereka bawa hingga mereka dewasa (Carson et al., 2015). Lebih lanjut, periode ini juga menentukan cara berpikir dan menghadapi masalah di masa yang akan datang. Fungsi eksekutif, yakni kumpulan kompetensi yang mencakup pengembangan memori kerja, peningkatan fleksibilitas kognitif, dan kemampuan membuat pertimbangan yang matang berkembang paling cepat pada usia dini (Drever et al., 2015). Kemampuan kognitif dan linguistik yang terbentuk di usia dini sangat menentukan kesuksesan seseorang di sekolah, tempat kerja, dan lingkungannya (Harvard University, 2007).

Pendidikan keuangan dapat didefinisikan sebagai proses yang mencakup dan memperhitungkan berbagai kebutuhan individu dalam konteks sosial-ekonomi yang berbeda (Russia's G20 Presidency \& OECD, 2013:17). Sementara itu menurut Otoritas Jasa Keuangan (2020) pendidikan keuangan merupakan penanaman nilai-nilai pengelolaan keuangan serta kemampuan untuk mengakses produk-produk keuangan yang dibutuhkan, dalam rangka meningkatkan taraf hidup individu. Pemahaman mengenai literasi keuangan sangat penting untuk diajarkan pada usia dini karena akan melekat pada diri seseorang menjadi sebuah budaya untuk mengelola keuangan yang baik seperti mengutamakan kebutuhan daripada keinginan, kebiasaan menabung, minat berinvestasi, dan lain sebagainya (Fabris \& Luburić, 2016; Wagner \& Walstad, 2019). Literasi keuangan dapat ditingkatkan salah satunya melalui pendidikan keuangan (Kaiser \& Menkhoff, 2017). Namun, fakta di lapangan membuktikan bahwa masih banyak orang tua yang memiliki tingkat literasi keuangan yang rendah (Organisation for Economic Co-operation Development, 2020:14; Otoritas Jasa Keuangan, 2019) sehingga kurang siap untuk mengajarkan pengetahuan keuangan kepada anak-anak mereka di rumah. Oleh sebab itu, pendidikan keuangan perlu diajarkan di sekolah.

Penerapan pendidikan keuangan di sekolah akan dapat menjangkau seluruh siswa dalam memberikan pemahaman tentang pengelolaan keuangan dan sumber daya pribadi maupun rumah tangga yang benar (De Beckker, Compen, De Bock, \& Schelfhout, 2019). Pendidikan keuangan juga membantu perkembangan kognitif siswa dan sebagai bekal dalam memasuki jenjang pendidikan selanjutnya (Walstad et al., 2017).Pendidikan keuangan di sekolah yang diimbangi dengan penanaman pengetahuan keuangan oleh orang tua di rumah dapat mengurangi kemungkinan siswa untuk melakukan pinjaman atau hutang di masa mendatang (Fan \& Chatterjee, 2019). Lebih lanjut, menurut Yuwono (2021), terdapat tiga peran strategis untuk mendukung pendidikan keuangan anak usia dini. Peran pertama ada di 
tangan pemerintah dan sekolah berupa payung hukum yang melandasi aturan pendidikan keuangan pada anak usia dini. Peran kedua ada di tangan guru dan orang tua yang memberikan secara langsung pendidikan keuangan pada siswa. Terakhir, peran ketiga dapat disebut juga peran pendukung, yakni media masa, komunitas, organisasi, perusahaan, dan lain sebagainya yang memberikan sumbangan referensi mengenai topik-topik pendidikan keuangan bagi anak usia dini.

Proses pembelajaran pendidikan keuangan dapat dibagi menjadi tiga tahap yang terdiri dari perencanaan, pelaksanaan, dan evaluasi. Tahap perencanaan diawali dengan penyusunan rancangan pembelajaran oleh guru. Rancangan pembelajaran tersebut meliputi perencanaan kegiatan pembelajaran, penyusunan program semester (prosem), penyusunan Rencana Pelaksanaan Pembelajaran Mingguan (RPPM), dan penyusunan Rencana Pelaksanaan Pembelajaran Harian atau RPPH (Lestariningrum, 2017:61-63). Selanjutnya ketika pelaksanaan pembelajaran, guru memberikan materi pendidikan keuangan kepada siswa menggunakan media dan model pembelajaran tertentu. Berdasarkan Holden, Kalish, Scheinholtz, \& Dietrich (2009:54), materi pendidikan keuangan di Amerika Serikat meliputi angka, waktu, uang dan pendapatan, pasar dan pertukaran, lembaga keuangan, pilihan (keputusan keuangan), nilai sosial, dan kebiasaan menabung. Sementara itu materi pendidikan keuangan menurut OJK diantaranya adalah mengetahui konsep dan jenis uang, fungsi uang dalam kehidupan, perbedaan kebutuhan dan keinginan, pentingnya kebiasaan menabung, dan kesadaran untuk berbagi kepada orang yang lebih membutuhkan (Otoritas Jasa Keuangan, 2020:4-5). Materi pendidikan keuangan yang dianjurkan oleh OJK selanjutnya akan digunakan sebagai pembanding materi yang telah diajarkan di PAUD.

Beberapa media yang sesuai dengan perkembangan zaman yang dapat digunakan untuk menyalurkan materi pendidikan keuangan pada siswa diantaranya adalah media berbasis digital, seperti: ebook, media visual seperti seperti foto, gambar, atau ilustrasi, dan media interaktif seperti adalah permainan, simulasi, dan aplikasi (OECD, 2019). Adapun model dan strategi pembelajaran yang cocok digunakan untuk melaksanakan pembelajaran pendidikan keuangan pada anak usia dini diantaranya adalah permainan sosio-dramatis, pembelajaran kooperatif, pembelajaran berbasis proyek (project based learning), bermain peran (role playing), dan problem solving (Birbili \& Kontopoulou, 2015).

Hasil temuan penelitian menunjukkan hanya sedikit negara yang mengadakan penilaian atau evaluasi untuk pendidikan keuangan (Council for Economic Education, 2018). Hal ini dikarenakan pendidikan keuangan yang ada di sekolah diintegrasikan dengan mata pelajaran lain, seperti matematika atau ekonomi, sehingga tidak terdapat ujian formal seperti ulangan harian, Penilaian Tengah Semester (PTS), maupun Penilaian Akhir Semester (PAS) tentang materi pendidikan keuangan (OECD, 2019:84). Fenomena tersebut juga serupa dengan yang terjadi di Indonesia. Hingga saat ini, pendidikan keuangan masih belum menjadi materi pelajaran atau tema wajib di kurikulum pendidikan anak usia dini (Wahyuni \& Reswita, 2020). Penyebabnya adalah untuk mencegah terjadinya kelebihan muatan (overload) pada kurikulum (Cordero, Gil-Izquierdo, \& Pedraja-Chaparro, 2019). Akibatnya hingga saat ini tidak ada standar baku untuk evaluasi pembelajaran pendidikan keuangan. Namun meski begitu, guru tetap dapat melaksanakan evaluasi pembelajaran pendidikan keuangan. Khusus untuk PAUD, guru dapat mengadopsi beberapa teknik pada pedoman penilaian yang dikeluarkan oleh Direktorat Pembinaan Pendidikan Anak Usia Dini (2018:5). Teknik tersebut diantaranya adalah ceklis, catatan anekdot, dan penilaian hasil karya.

Penelitian terdahulu yang relevan dengan penelitian ini adalah penelitian Rapih (2016) yang menyebutkan bahwa pendidian keuangan di Indonesia masih belum terlaksana secara optimal, baik dalam lingkup keluarga maupun sekolah. Hasil tersebut sejalan dengan penelitian Ariyani (2018) yang menunjukkan bahwa pendidikan keuangan di tingkat Taman Kanak-Kanak (TK) belum diterapkan secara maksimal. Sementara penelitian Krisdayanthi (2019) menyebutkan bahwa financial parenting yakni berupa kebiasaan gemar menabung perlu diberikan sejak dini karena akan berdampak pada kemampuan pengelolaan keuangan anak 
yang lebih baik ketika dewasa. Penelitian ini membawa sejumlah kebaruan yang diantaranya adalah adanya perbandingan materi pendidikan keuangan yang diajarkan di PAUD dengan materi terbaru yang dianjuran oleh OJK tahun 2020 dan analisis proses evaluasi pembelajaran pendidikan keuangan yang dilakukan di PAUD. Adapun tujuan dari penelitian ini adalah menganalisis proses pembelajaran pendidikan keuangan yang meliputi tahap perencanaan, pelaksanaan, dan evaluasi pada jenjang PAUD. Berdasarkan paparan tersebut, penulis tertarik untuk mengkaji lebih lanjut mengenai "Analisis Implementasi Pendidikan Keuangan pada Jenjang Pendidikan Anak Usia Dini (PAUD)"

\section{METODOLOGI}

Penelitian ini termasuk ke dalam jenis penelitian kualitatif dengan pendekatan studi kasus. Metode penelitian kualitatif dipilih karena peneliti ingin menggali informasi sedalamdalamnya untuk menjelaskan suatu fenomena yang terjadi. Sedangkan pendekatan studi kasus merupakan desain penelitian yang mengembangkan analisis mendalam atas suatu permasalahan (Creswell, 2014:19). Permasalahan yang diselidiki dalam penelitian ini adalah implementasi pembelajaran pendidikan keuangan di lembaga Pendidikan Anak Usia Dini (PAUD). Teknik pengumpulan data dilakukan dengan cara wawancara mendalam dan analisis dokumen. Dokumen yang dianalisis meliputi silabus, RPPH yang disusun guru, dan foto pada saat pembelajaran berlangsung. Wawancara yang dilakukan adalah wawancara tidak terstruktur (terbuka).

Informan dalam penelitian ini adalah tiga orang guru PAUD yang masing-masing berasal dari PAUD Modern Bunda Sayang, PAUD Aisyiyah, dan PAUD Permata Bunda. Ketiga PAUD tersebut terletak di Kecamatan Geneng, Kabupaten Ngawi, Jawa Timur. Waktu penelitian dilaksanakan pada tanggal 26-27 Maret 2021. Pengujian validitas data pada penelitian ini menggunakan teknik triangulasi sumber data. Triangulasi sumber data dilakukan dengan cara membandingkan data hasil wawancara dengan silabus, RPPH, media pembelajaran, arsip foto ketika pembelajaran pendidikan keuangan dilaksanakan, dan dokumen terkait lainnya. Teknik analisis data menggunakan teknik analisis interaktif dengan empat langkah kegiatan yakni pengumpulan data, reduksi data, penyajian data, serta penarikan kesimpulan dan verifikasi data (Miles \& Huberman, 2009). Adapun alur yang ditempuh dalam proses analisis data adalah sebagai berikut:

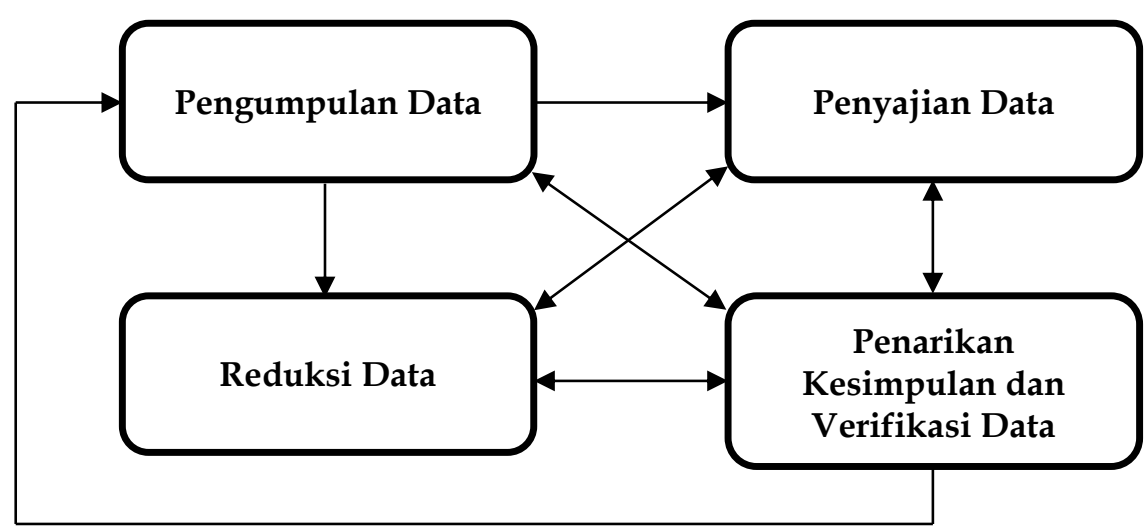

Gambar 1. Teknik Analisis Interaktif (Miles \& Huberman, 2009).

\section{HASIL DAN PEMBAHASAN}

\section{Implementasi Pendidikan Keuangan di PAUD Modern Bunda Sayang}

Implementasi pembelajaran pendidikan keuangan pada PAUD Modern Bunda Sayang diawali dari tahap perencanaan yang berupa penyusunan Rencana Pelaksanaan Pembelajaran Harian (RPPH), persiapan materi, media, serta kegiatan yang akan dilaksanakan selama pembelajaran. Selanjutnya pada tahap pelaksanaan, guru menyampaikan materi pendidikan 
keuangan kepada siswa. Materi pendidikan keuangan yang diajarkan oleh guru mencakup konsep, jenis, dan bentuk uang, kegunaan uang, pentingnya kebiasaan menabung, kesadaran untuk berbagi kepada orang yang lebih membutuhkan, dan pengenalan lembaga keuangan. Materi pentingnya kebiasaan menabung diajarkan dengan menginstruksikan siswa untuk menabung setiap hari di celengan yang sudah disediakan oleh sekolah. Materi kesadaran berbagi kepada orang yang lebih membutuhkan diajarkan dengan mewajibkan siswa untuk membayar infaq setiap hari Senin dan iuran dana sosial apabila terdapat siswa yang sedang sakit atau mengalami musibah. Sementara materi pengenalan lembaga keuangan diajarkan dengan cara mengajak siswa berkunjung langsung ke bank. Perbandingan materi pendidikan keuangan yang diajarkan PAUD Modern Bunda Sayang dengan anjuran OJK dapat dilihat pada tabel 1.

Tabel 1. Perbandingan Materi Pendidikan Keuangan PAUD Modern Bunda Sayang dengan OJK

\begin{tabular}{clcc}
\hline No. & \multicolumn{1}{c}{ Materi } & $\begin{array}{c}\text { Otoritas Jasa } \\
\text { Keuangan (OJK) }\end{array}$ & $\begin{array}{c}\text { PAUD Modern } \\
\text { Bunda Sayang }\end{array}$ \\
\hline $\mathbf{1}$ & Mengetahui konsep dan jenis uang & Ada & Ada \\
$\mathbf{2}$ & Fungsi uang dalam kehidupan & Ada & Ada \\
$\mathbf{3}$ & Perbedaan kebutuhan dan keinginan & Ada & Tidak ada \\
$\mathbf{4}$ & Pentingnya kebiasaan menabung & Ada & Ada \\
$\mathbf{5}$ & Kesadaran untuk berbagi kepada orang yang & Ada & Ada \\
& lebih membutuhkan & Tidak ada & Ada \\
$\mathbf{6}$ & Pengenalan lembaga keuangan & &
\end{tabular}

Sumber: Otoritas Jasa Keuangan (2020:4-5), data diolah peneliti (2021)

Berdasarkan tabel 1, dapat diketahui bahwa materi-materi pendidikan keuangan di PAUD Modern Bunda Sayang belum sesuai dengan anjuran OJK. Terdapat satu materi anjuran OJK yang tidak diajarkan di PAUD ini yakni perbedaan kebutuhan dan keinginan. Namun PAUD Modern Bunda Sayang memberikan materi yang tidak terdapat dalam anjuran OJK, yakni mengenai pengenalan lembaga keuangan. PAUD Modern Bunda Sayang sudah tepat memberikan materi tersebut karena pada negara maju seperti Amerika, materi tersebut sudah diajarkan di jenjang PAUD (Holden et al., 2009).

Selanjutnya masih dalam tahap pelaksanaan pembelajaran, guru menggunakan media pembelajaran yang sudah bervariasi. Media tersebut terdiri dari uang mainan, uang koin palsu yang terbuat dari kardus yang ditempeli gambar uang koin yang telah di print, uang asli, video pembelajaran, dan power point. Namun sayangnya sumber belajar seperti text book, modul, LKS, dan sebagainya tidak tersedia bagi siswa. Padahal ketersediaan sumber belajar sangat penting untuk memperdalam pengetahuan siswa (Hadi \& Farida, 2012). Hasil ini sesuai dengan penelitian Ariyani (2018) yang juga menemukan bahwa ketersediaan sumber belajar pendidikan keuangan untuk anak pra sekolah masih belum memadahi. Sejauh ini materi yang dipelajari siswa disampaikan secara langsung oleh guru dengan metode ceramah, demonstrasi, tanya jawab, dan praktek jual beli. Namun dari sekian jenis metode, metode yang paling dominan digunakan oleh guru adalah ceramah.

Sistem evaluasi pembelajaran pendidikan keuangan pada PAUD Modern Bunda Sayang menggunakan teknik tes lisan. Guru memilih teknik tersebut karena siswa masih belum dapat menulis sehingga tidak memungkinkan untuk melaksanakan tes tulis. Tes lisan dilaksanakan menggunakan dialog dan kata-kata sehari-hari agar siswa mudah memahami pertanyaan yang diajukan. Guru dalam hal ini menggunakan uang asli untuk untuk menguji sejauh mana pemahaman siswa terhadap konsep uang. Hasil temuan tersebut selaras dengan penelitian DeLuca, Pyle, Braund, dan Faith (2020) yang menyebutkan bahwa metode tanya jawab secara lisan menjadi salah satu bentuk evaluasi pembelajaran yang banyak digunakan pada penilaian anak usia dini. Selanjutnya pendidikan keuangan pada PAUD Modern Bunda 
Sayang tidak menjadi suatu tema atau sub tema tertentu. Sekolah memasukkan materi pendidikan keuangan pada sub tema Numerasi. Hasil penelitian ini selaras dengan penelitian Salas-Velasco, Moreno-Herrero, dan Sánchez-Campillo (2020) yang mengungkapkan bahwa mengintegrasikan materi pendidikan keuangan pada pelajaran Matematika dapat meningkatkan kemampuan literasi keuangan.

\section{Implementasi Pendidikan Keuangan di PAUD Aisyiyah}

Implementasi pembelajaran pendidikan keuangan pada PAUD Aisyiyah diawali dari tahap perencanaan. Guru tidak membuat RPPH dalam tahap ini namun tetap mempersiapkan materi dan media yang akan digunakan dalam pembelajaran. Kemudian pada tahap pelaksanaan, guru menyampaikan materi kepada siswa dengan metode ceramah. Materi pendidikan keuangan pada PAUD Aisyiyah terdiri dari konsep, jenis, dan fungsi uang, lembaga keuangan, tempat terjadinya transaksi jual beli, pentingnya kebiasaan menabung, dan kesadaran untuk berbagi kepada orang yang lebih membutuhkan. Materi pentingnya kebiasaan menabung ditanamkan guru dengan cara menginstruksikan masing-masing siswa membawa celengan sendiri dari rumah untuk diletakkan di sekolah. Celengan tersebut wajib diisi oleh siswa setiap hari dengan nominal yang tidak ditentukan. Selanjutnya pada materi kesadaran untuk berbagi kepada yang lebih membutuhkan, guru menerapkan infaq siswa setiap hari Jum'at dan juga iuran dana sosial (dansos) ketika terdapat siswa yang sakit atau sedang mengalami musibah. Perbandingan materi pendidikan keuangan yang diajarkan PAUD Aisyiyah dengan anjuran OJK dapat dilihat pada tabel 2.

Tabel 2. Perbandingan Materi Pendidikan Keuangan PAUD Aisyiyah dengan OJK

\begin{tabular}{clcc}
\hline No. & \multicolumn{1}{c}{ Materi } & $\begin{array}{c}\text { Otoritas Jasa } \\
\text { Keuangan (OJK) }\end{array}$ & $\begin{array}{c}\text { PAUD } \\
\text { Aisyiyah }\end{array}$ \\
\hline $\mathbf{1}$ & Mengetahui konsep dan jenis uang & Ada & Ada \\
$\mathbf{2}$ & Fungsi uang dalam kehidupan & Ada & Ada \\
$\mathbf{3}$ & Perbedaan kebutuhan dan keinginan & Ada & Tidak ada \\
$\mathbf{4}$ & Pentingnya kebiasaan menabung & Ada & Ada \\
$\mathbf{5}$ & Kesadaran untuk berbagi kepada orang yang lebih & Ada & Ada \\
& membutuhkan & & \\
$\mathbf{6}$ & Pengenalan lembaga keuangan & Tidak ada & Ada \\
$\mathbf{7}$ & Tempat terjadinya transaksi jual beli & Tidak ada & Ada \\
\hline
\end{tabular}

Sumber: Otoritas Jasa Keuangan (2020:4-5), data diolah peneliti (2021)

Berdasarkan tabel 2, diketahui bahwa materi pendidikan keuangan yang diajarkan PAUD Aisyiyah belum sesuai dengan anjuran OJK. Terdapat satu materi OJK yang tidak diajarkan oleh PAUD Aisyiyah yakni perbedaan kebutuhan dan keinginan. Materi yang tidak terdapat pada anjuran OJK namun diajarkan PAUD Aisyiyah adalah pengenalan lembaga keuangan dan tempat terjadinya transaksi jual beli. Kedua materi tersebut sebenarnya sudah tepat diberikan kepada siswa karena di negara lain seperti Amerika, materi tersebut diajarkan di jenjang PAUD (Holden et al., 2009).

Selain pembelajaran di kelas, guru mengadakan kegiatan praktek jual beli yang dilakukan di luar sekolah. Lokasi praktek jual beli berada di pasar yang terletak tidak jauh dari PAUD Aisyiyah. Sebelum berkunjung ke pasar, siswa terlebih dahulu diberikan materi pendidikan keuangan di sekolah. Adapun kegiatan siswa selama di pasar adalah melakukan praktek pembelian jajan atau mainan dengan batas harga tidak boleh melebihi Rp2.000. Media pembelajaran yang digunakan guru ketika mengajarkan pendidikan keuangan hanyalah uang asli (uang tunai). Tidak digunakannya media lain seperti media digital atau media interaktif dikarenakan fasilitas PAUD Aisyiyah yang masih terbatas. Sumber belajar siswa seperti text book, modul, LKS, dan sebagainya juga tidak tersedia. Hasil tersebut selaras dengan temuan 
penelitian Ariyani (2018) yang menyebutkan bahwa pelaksanaan pendidikan keuangan anak usia dini di sekolah memerlukan tambahan sarana dan prasarana pendukung.

Selanjutnya tahap evaluasi pembelajaran di PAUD Aisyiyah lebih ke arah mereview materi yang telah dipelajari hari ini pada akhir sesi pembelajaran. PAUD Aisyiyah tidak menyelenggarakan evaluasi formal untuk pendidikan keuangan. Evaluasi yang dilakukan adalah mereview materi yang telah dipelajari hari ini di akhir sesi pembelajaran, apakah materi yang disampaikan guru diterima dengan baik oleh siswa atau tidak. Alasannya karena materi pendidikan keuangan di PAUD Aisyiyah tidak menjadi tema atau sub tema sendiri. Sekolah memasukkan materi pendidikan keuangan dalam tema lingkungan pada sub tema tempat umum. Guru akan memberikan materi pendidikan keuangan ketika membahas tempat umum tertentu yang berkaitan dengan transaksi keuangan, seperti misalnya bank, pasar, swalayan, dan lain sebagainya. Hasil temuan ini selaras dengan yang diungkapkan oleh Council for Economic Education, yakni mayoritas negara di dunia tidak menyelenggarakan evaluasi formal pembelajaran pendidikan keuangan. Hal ini dikarenakan pendidikan keuangan bukan merupakan suatu mata pelajaran. Evaluasi tersebut (misalpun ada) akan tergabung ke dalam mata pelajaran dimana pendidikan keuangan diintegrasikan Council for Economic Education (2018).

\section{Implementasi Pendidikan Keuangan di PAUD Permata Bunda}

PAUD Permata Bunda tidak menerapkan pendidikan keuangan dalam pembelajaran. Alasan guru tidak memberikan materi pendidikan keuangan dalam pembelajaran adalah karena materi pendidikan keuangan tidak terdapat dalam kurikulum PAUD. Selain itu guru beranggapan bahwa penanaman konsep keuangan menjadi tanggung jawab orang tua siswa di rumah. Namun guru setuju bahwa pendidikan keuangan penting untuk ditanamkan sejak usia dini. Guru secara tidak langsung tetap menanamkan nilai-nilai pendidikan keuangan pada kondisi tertentu di luar pembelajaran. Misalnya ketika siswa terlalu banyak jajan, guru akan menegur siswa agar tidak boros dan lebih baik menyisihkan uangnya untuk ditabung.

Hasil temuan ini selaras dengan penelitian Russia's G20 Presidency dan OECD (2013) yang menyebutkan bahwa Bank Indonesia dan Kementerian Pendidikan dan Kebudayaan Indonesia saat ini fokus pada penyelenggaraan pendidikan keuangan bagi siswa SD dan SMP. Hasil penelitian ini juga selaras dengan Messy dan Monticone (2016) yang menyebutkan bahwa sejak Juli 2014, pendidikan keuangan di Indonesia diperkenalkan di SMA, sementara SMP dan SD menyusul kemudian. Jadi dapat disimpulkan bahwa saat ini pemerintah Indonesia masih fokus pada implementasi pendidikan keuangan di tingkat SD, SMP, dan SMA. Sementara di tingkat pendidikan anak usia dini, pemerintah baru mengeluarkan anjuran melalui Otoritas Jasa Keuangan untuk memberikan pendidikan keuangan pada siswa usia dini. Anjuran tersebut tidak bersifat wajib sehingga sangat wajar apabila ditemui terdapat lembaga pendidikan anak usia dini yang tidak mengimplementasikan pendidikan keuangan pada pembelajaran mereka.

\section{Implikasi Hasil Temuan Implementasi Pendidikan Keuangan di PAUD}

Berdasarkan hasil temuan yang telah dipaparkan di atas, diperoleh beberapa implikasi. Pertama, pendidikan keuangan harus menjadi bagian dari kurikulum sekolah. Hingga saat ini masih terdapat sekolah yang tidak memberikan materi pendidikan keuangan dalam pembelajaran, disebabkan pendidikan keuangan tidak termuat dalam kurikulum. Sedangkan sekolah yang sudah menerapkan pendidikan keuangan memiliki susunan materi yang berbeda-beda antar satu sekolah dengan sekolah lainnya. Hal ini dikarenakan kebanyakan guru tidak mengetahui adanya anjuran materi pendidikan keuangan yang dikeluarkan pemerintah melalui OJK. Oleh sebab itu, pemerintah harus menggabungkan pendidikan keuangan sebagai bagian dari kurikulum yang dilaksanakan sekolah. Pendidikan keuangan tidak perlu menjadi tema atau sub tema yang berdiri sendiri karena akan membuat 
beban kurikulum semakin berat (overload). Namun pendidikan keuangan dapat diintegrasikan pada tema atau sub tema tertentu yang relevan (Cordero et al., 2019; Salas-Velasco et al., 2020).

Kedua, pendidikan keuangan harus memiliki kerangka kerja yang jelas. Sekolah yang mengimplementasikan pendidikan keuangan dalam pembelajaran belum melaksanakan proses pembelajaran secara optimal. Hal ini dikarenakan tidak adanya bahan bacaan, acuan pelaksanaan pembelajaran, dan standar evaluasi yang dapat dijadikan sebagai acuan. Oleh sebab itu, harus terdapat kerangka kerja yang memuat secara jelas sasaran tujuan, outcome yang ingin dicapai, sumber daya yang profesional, serta panduan pelaksanaan dan evaluasi pembelajaran. Konten pembelajaran harus menyasar ranah kognitif, psikomotorik, dan afektif (Rapih, 2016). Selain itu diperlukan juga landasan hukum sebagai dasar aturan implementasi pendidikan keuangan pada anak usia dini (Yuwono, 2021).

Ketiga, pelaksanaan pendidikan keuangan harus didukung oleh semua pihak. Yuwono (2021) menyebutkan setidaknya terdapat beberapa pihak yang berperan dalam implementasi pendidikan keuangan anak usia dini. Pihak pertama adalah pemerintah dan institusi pendidikan. Pemerintah sebagai perumus kebijakan harus membuat kebijakan yang jelas mengenai implementasi pendidikan keuangan di PAUD. Pemerintah dan sekolah juga harus menyediakan dukungan pendanaan, fasilitas, dan sumber belajar yang memadai. Pihak kedua adalah orang tua dan guru. Guru harus memiliki kompetensi yang profesional dan menguasai konsep literasi keuangan. Orang tua harus mendukung peran guru dengan tetap memberikan pemahaman mengenai literasi keuangan di rumah. Namun sayangnya masyarakat Indonesia masih menganggap membahas masalah keuangan kepada anak adalah hal yang tabu (Pulungan, Khairani, Arda, Koto, \& Kurnia, 2019). Budaya ini harus diubah agar Indonesia tidak tertinggal dalam hal literasi keuangan. Selanjutnya pihak ketiga adalah media masa, komunitas, pemerhati/ pengamat pendidikan, perusahaan, atau organisasi yang peduli terhadap anak juga dibutuhkan dalam menyajikan konten-konten edukasi pendidikan keuangan anak usia dini baik melalui platform offline maupun online.

\section{SIMPULAN}

Hasil penelitian menunjukkan bahwa belum semua PAUD memberikan pelajaran pendidikan keuangan pada anak didiknya. Hal ini disebabkan karena pendidikan keuangan tidak terdapat dalam kurikulum, sehingga penerapannya menjadi kebijakan masing-masing sekolah. Apabila hal ini dibiarkan maka Indonesia dapat tertinggal dalam hal literasi keuangan, padahal saat ini literasi keuangan menjadi salah satu keterampilan penting yang wajib dimiliki. Untuk mengatasi permasalahan tersebut, maka pendidikan keuangan harus dimasukkan ke dalam kurikulum sekolah dan memiliki kerangka kerja yang mengatur dengan jelas pelaksanaannya. Lebih lanjut, penerapan pendidikan keuangan juga harus didukung oleh semua pihak mulai dari pemerintah, institusi pendidikan, orang tua, guru, dan pihak lain yang terkait.

\section{UCAPAN TERIMA KASIH}

Peneliti mengucapkan terimakasih kepada Allah S.W.T atas limpahan rahmat yang telah diberikan-Nya, kepada ibu peneliti ibu Umi Ridowati dan adik peneliti Yolanda Andara yang selalu memberikan motivasi dan dukungan kepada peneliti, kepada bapak ibu dosen Magister Pendidikan Ekonomi Universitas Sebelas Maret khususnya ibu Dr. Susilaningsih, M.Bus yang telah membimbing peneliti dalam penyusunan artikel ini, kepada ibu Anita Solihatul Wahidah M.Pd.I., M.Si selaku guru PAUD Modern Bunda Sayang, ibu Ami Harianti S.Pd selaku guru PAUD Aisyiyah, ibu Endah Wahyuni S.Pd selaku guru PAUD Permata Bunda, dan seluruh pihak yang telah berkontribusi dalam penulisan artikel ini. 


\section{DAFTAR PUSTAKA}

Ariyani, D. (2018). Pendidikan Literasi Keuangan pada Anak Usia Dini di TK Khalifah Purwokerto. Yinyang Jurnal Studi Islam Gender Dan Anak, 13(12). https://doi.org/10.24090/yinyang.v13i2.2100

Birbili, M., \& Kontopoulou, M. (2015). Financial Education for Preschoolers: Preparing Young Children for the 21st Century. Childhood Education, 91(1), 46-53. https://doi.org/10.1080/00094056.2015.1001670

Carson, V., Kuzik, N., Hunter, S., Wiebe, S. A., Wiebe, S. A., Friedman, A., ... Hinkley, T. (2015). Systematic review of sedentary behavior and cognitive development in early childhood. Preventive Medicine, 78, 115-122. https://doi.org/10.1016/i.ypmed.2015.07.016

Cordero, J. M., Gil-Izquierdo, M., \& Pedraja-Chaparro, F. (2019). Financial education and student financial literacy: A cross-country analysis using PISA 2012 data. Social Science Journal. https://doi.org/10.1016/j.soscij.2019.07.011

Council for Economic Education. (2018). Survey of the States: Economic and Personal Finance Education in our Nation's Schools. Retrieved from https://www.councilforeconed.org/wp-content/uploads/2018/02/2018-SOS-Layout18.pdf

Creswell, J. W. (2014). Research Design: Qualitative, Quantitative, and Mixed Methods Approaches (4th ed.). SAGE Publications Inc.

De Beckker, K., Compen, B., De Bock, D., \& Schelfhout, W. (2019). The capabilities of secondary school teachers to provide financial education. Citizenship, Social and Economics Education, 18(2), 66-81. https:// doi.org/10.1177/2047173419850152

DeLuca, C., Pyle, A., Braund, H., \& Faith, L. (2020). Leveraging assessment to promote kindergarten learners' independence and self-regulation within play-based classrooms. Assessment in Education: Principles, Policy \& Practice, 27(4), 394-415. https://doi.org/10.1080/0969594X.2020.1719033

Direktorat Pembinaan Pendidikan Anak Usia Dini. (2018). Penilaian Pembelajaran Anak Usia Dini. Jakarta: Kementerian Pendidikan dan Kebudayaan.

Drever, A. I., Odders-White, E., Kalish, C. W., Else-Quest, N. M., Hoagland, E. M., \& Nelms, E. N. (2015). Foundations of Financial Well-Being: Insights into the Role of Executive Function, Financial Socialization, and Experience-Based Learning in Childhood and Youth. The Journal of Consumer Affairs, 49(1), 13-38. https:// doi.org/10.1111/joca.12068

Fabris, N., \& Luburić, R. (2016). Financial Education of Children and Youth. Journal of Central Banking Theory and Practice, 2, 65-79. https:// doi.org/10.1515/jcbtp-2016-0011

Fan, L., \& Chatterjee, S. (2019). Financial Socialization, Financial Education, and Student Loan Debt. Journal of Family and Economic Issues, 40(1), 74-85. https:// doi.org/10.1007/s10834-018$\underline{9589-0}$

Goyal, K., \& Kumar, S. (2021). Financial literacy: A systematic review and bibliometric analysis. International Journal of Cunsomer Studies, 45, 80-105. https:// doi.org/10.1111/ijcs.12605

Hadi, S., \& Farida, F. S. (2012). Pengaruh minat, kemandirian, dan sumber belajar terhadap prestasi belajar siswa pada mata pelajaran IPS kelas VII SMP Negeri 5 Ungaran. Jurnal Pendidikan Ekonomi Dinamika Pendidikan, 7(1), 8-13. https://doi.org/10.21831/jep.v8i1.710

Harvard University. (2007). InBrief: The Science of Early Childhood Development. Retrieved from https:// developingchild.harvard.edu/resources/inbrief-science-of-ecd/

Holden, K., Kalish, C., Scheinholtz, L., \& Dietrich, D. (2009). Financial Literacy Programs Targeted on Pre-School Children: Development and Evaluation.

Kaiser, T., \& Menkhoff, L. (2017). Does Financial Education Impact Financial Literacy and Financial Behavior, and If So, When? The World Bank Economic Review, 31(3), 611-630. https://doi.org/10.1093/wber/lhx018

Krisdayanthi, A. (2019). Penerapan financial parenting (gemar menabung) pada anak usia dini. Pratama Widya: Jurnal Pendidikan Anak Usia Dini, 4(1). https://doi.org/10.25078/pw.v4i1.1063

Kurowski, Ł. (2021). Household's Overindebtedness during the COVID-19 Crisis: The Role of Debt and Financial Literacy. Risks, 9(4). https://doi.org/10.3390/risks9040062 
Lestariningrum, A. (2017). Perencanaan Pembelajaran Anak Usia Dini. Nganjuk: Adjie Media Nusantara.

Lian, B., Kristiawan, M., Primasari, D. A. G., Anggung, M., \& Prasetyo, M. (2020). Teachers' model in building students' character. Journal of Critical Reviews, 7(14). https://doi.org/10.31838/jcr.07.14.165

Messy, F.-A., \& Monticone, C. (2016). Financial Education Policies in Asia and the Pacific. https://doi.org/10.1787/5jm5b32v5vvc-en

Miles, M. B., \& Huberman, A. M. (2009). Analisis Data Kualitatif. UI Press.

OECD. (2019). Policy Handbook on Financial Education for Young People in the Commonwealth of Independent States. Organisation for Economic Co-operation and Development.

Organization for Economic Co-operation Development. (2020). International Survey of Adult Financial Literacy. Retrieved from www.oecd.org/financial/education/launchoftheoecdinfeglobalfinancialliteracysurveyre port.htm

Organization for Economic Co-operation Development. (2021). PISA 2021 Financial Literacy Analytical and Assessment Framework. Retrieved from www.oecd.org

Otoritas Jasa Keuangan. (2019). Survei Nasional Literasi dan Inklusi Keuangan 2019. Retrieved from https:// www.ojk.go.id/id/berita-dan-kegiatan/publikasi/Pages/Survei-NasionalLiterasi-dan-Inklusi-Keuangan-2019.aspx

Otoritas Jasa Keuangan. (2020). Menumbuhkan Kecakapan Literasi Keuangan pada Anak Usia Dini (1st ed.). Retrieved from https://sikapiuangmu.ojk.go.id

Pulungan, D. R., Khairani, L., Arda, M., Koto, M., \& Kurnia, E. (2019). Memotivasi Anak Usia Dini Menabung Demi Masa Depan. Proseding Seminar Nasional Kewirausahaan, 296-301. https:// doi.org/ 10.30596/snk.v1i1.3631

Rapih, S. (2016). Pendidikan literasi keuangan pada anak: mengapa dan bagaimana? Scholaria Jurnal Pendidikan Dan Kebudayaan, 6(2). https://doi.org/10.24246/j.scholaria.2016.v6.i2.p14-28

Russia's G20 Presidency, \& OECD. (2013). Advancing National Strategies for Financial Education. Retrieved from https://www.oecd.org/finance/financialeducation/G20_OECD_NSFinancialEducation.pdf

Salas-Velasco, M., Moreno-Herrero, D., \& Sánchez-Campillo, J. (2020). Teaching financial education in schools and students' financial literacy: A cross-country analysis with PISA data. International Journal of Finance and Economics. https://doi.org/10.1002/ijfe.2005

Sansone, D., Rossi, M., \& Fornero, E. (2019). "Four Bright Coins Shining at Me": Financial Education in Childhood, Financial Confidence in Adulthood. The Journal of Consumer Affairs, 53(2), 630-651. https:// doi.org/10.1111/joca.12207

Wagner, J., \& Walstad, W. B. (2019). The Effects of Financial Education on Short-Term and LongTerm Financial Behaviors. Journal of Consumer Affairs, 53(1), 234-259. https://doi.org/10.1111/joca.12210

Wahyuni, S., \& Reswita. (2020). Persepsi Guru terhadap Pendidikan Sosial Finansial pada Anak Usia Dini menggunakan Media Loose Parts. Jurnal Obsesi : Jurnal Pendidikan Anak Usia Dini, 4(1), 962-970. https://doi.org/10.31004/obsesi.v4i2.493

Walstad, W., Urban, C., Asarta, C. J., Breitbach, E., Bosshardt, W., Heath, J., ... Xiao, J. J. (2017). Perspectives on evaluation in financial education: Landscape, issues, and studies. The Journal of Economic Education, 93-112. https://doi.org/10.1080/00220485.2017.1285738

World Economic Forum. (2015). New Vision for Education Unlocking the Potential of Technology. Retrieved from www.weforum.org

Yuwono, W. (2021). Konseptualisasi Peran Strategis dalam Pendidikan Literasi Keuangan Anak melalui Pendekatan Systematic Review. Jurnal Obsesi: Jurnal Pendidikan Anak Usia Dini, 5(2). https://doi.org/10.31004/obsesi.v5i2.663 